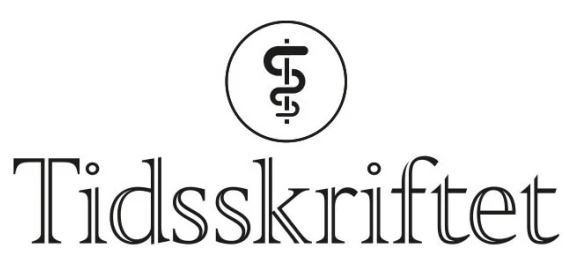

DEN NORSKE LEGEFORENING

\title{
Håndbok for kolorektalkirurger
}

\author{
ANMELDELSER
}

BJ $\varnothing R$ R STEINAR OLDEN NEDREB $\varnothing$

Seksjon for gastrokirurgi

Stavanger universitetssjukehus

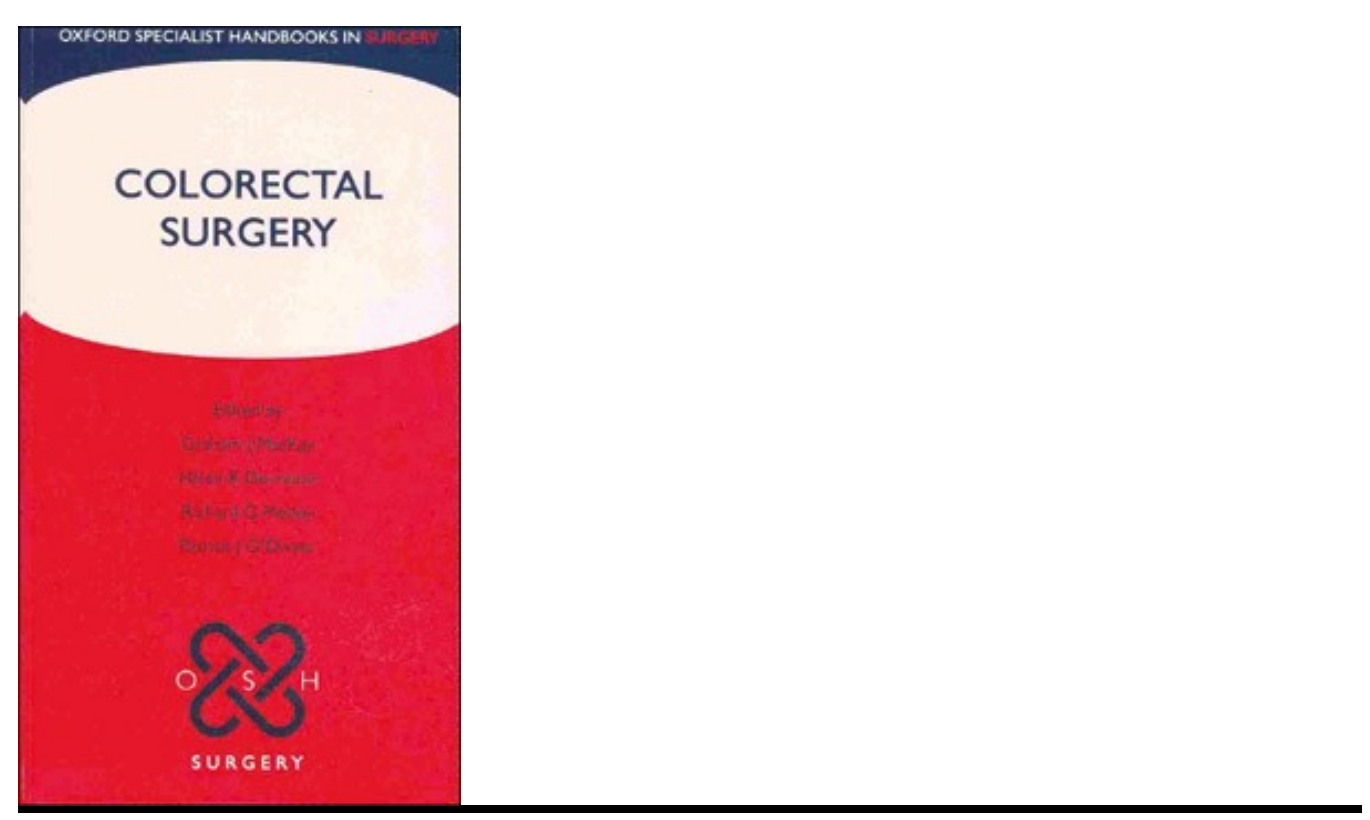

MacKay, Graham J.

Dorrance, Helen R.

Molloy, Richard G.

Colorectal surgery

602 s, tab, ill. Oxford: Oxford University Press, 2010. Pris GBP 45

ISBN 978-0-19-957177-2

Denne utgivelsen inngår i serien Oxford Specialist Handbooks og er beregnet på frakkelommen til assistentleger i spesialisering. Colorectal surgery er laget for den britiske spesialiteten i kolorektal kirurgi og er ment å dekke pensumet for den avsluttende spesialisteksamenen. 
Den byr på et omfattende spektrum fra anatomi, fysiologi til utredning, deriblant litt om f.eks. anal manometri og defekografi. Det er kapitler om vanlige problemstillinger som man møter på poliklinikken og hos innlagte pasienter, men også mer sjeldne lidelser. De vanligste sykdommene er forholdsvis omfattende dekket, det er f.eks. 8 o sider om malign kolorektal sykdom og 80 sider om inflammatorisk tarmsykdom. Men også mindre temaer som obstruktiv defekasjon, analstenose og rectumprolaps er med. Det er en egen sesjon om akutt kolorektal kirurgi, som bl.a. berører ileus, colonperforasjon, anastomoselekkasje og akutte colonblødninger. I slutten kommer det strektegninger av de vanligst brukte kolorektale inngrep samt et litt spennende kapittel om våre kanskje nærmeste kirurgiske kolleger når det gjelder bekkenet - urologene og gynekologene. Man går gjennom de vanligst tilgrensende temaer som f.eks. endometriose, salpingitt, ureterskader og ulike kreftsykdommer i bekkenet.

Colorectal surgery er solid innbundet, den er myk å ha i en frakkelomme og for øvrig også rikholdig illustrert med over 200 figurer.

Alt i alt vil jeg si at dette er en bok tettpakket med oppdatert, komprimert informasjon om det meste innenfor det kolorektale fagfeltet. Målgruppen i Norge blir først og fremst assistentleger som skal bli gastrokirurger. Også for noe mer erfarne kolleger kan dette være et greit oppslagsverk når man raskt trenger kortversjonen innenfor et tema. Den dekker det viktigste av det man som assistentlege trenger å vite om nedre gastrokirurgi, og praksis i Storbritannia virker å være temmelig lik den norske. Mangelen er at den ikke dekker øvre gastrokirurgi. Men den dekker et imponerende antall ulike temaer kort og konsist, så den kan absolutt brukes til å slå opp i kjapt i ulike sammenhenger. Den er velskrevet, går rett til sakens kjerne og inneholder noen få gode nøkkelreferanser til hvert tema. Colorectal surgery kan være god å ha på avdelingen dersom man skal oppdatere sin egen metodebok.

Publisert: 23. august 2011. Tidsskr Nor Legeforen. DOI:10.4045/tidsskr.11.0478

(C) Tidsskrift for Den norske legeforening 2023. Lastet ned fra tidsskriftet.no 26. april 2023. 